\title{
HYPNO-BREASTFEEDING REDUCES ANXIETY OF BREASTFEEDING MOTHERS DURING THE COVID-19 PANDEMIC
}

\author{
Ni Nyoman Deni Witari*, Ketut Novia Arini, Ni Made Widiastuti \\ "Midwifery Department, Health Polytechnic of Bali, Jl. Piranha No.2 Pegok, Sesetan, Denpasar Selatan, Bali \\ 80223 telp. (0361) 720471, Indonesia \\ *Corresponding author \\ E-mail: dnoksaelus@yahoo.com
}

\begin{abstract}
Background: COVID-19 pandemic is a time when a lot of people are vulnerable for virus transmission which can cause anxiety and psychological disorders, including for postpartum and breastfeeding mothers. The harmful effects of postpartum anxiety, if not managed properly, can affect the physical and psychological health of both mother and baby. The purpose of this study was to determine the effect of hypno-breastfeeding on reducing postnatal maternal anxiety.

Methods: The design of this study was quasi-experimental design with one pretest-posttest group, without control group. This study was conducted at the South Denpasar Health Center III with samples of 32 respondents who met the inclusion criteria. The sampling technique used in this research was purposive sampling. The independent variable in this study was hypno-breastfeeding and the dependent variable was decreased anxiety. Data were collected using the Zung Self-rating Anxiety Scale (ZSAS) questionnaire and data analysis was carried out using univariate and bivariate test (t test).

Result: The results showed that most of the breastfeeding mother before being given hypno-breastfeeding (65\%) experienced moderate anxiety and after being given hypnobreastfeeding, most mother (47\%) experienced mild anxiety. The bivariate results show the $\mathrm{t}$-count value of 6.851 with $\mathrm{p}$-value $(0.000)$ which showed that there is a significant effect of hypno-breastfeeding on reducing anxiety of breastfeeding mothers.

Conclusion: Hypno-breastfeeding can be applied to breastfeeding mothers to reduce anxiety and make exclusive breastfeeding successful.
\end{abstract}

Keywords: Hypno-breastfeeding, Postpartum and breastfeeding mothers, Anxiety 


\section{INTRODUCTION}

At early 2020, the whole world was shocked by the emergence of a new virus namely the coronavirus, that caused Coronavirus disease 2019 (COVID-19) which first appeared in Wuhan City, China in December 2019. On March 11, 2020 World Health Organization (WHO) has declared the COVID-19 outbreak as a global pandemic, because it spread so quickly to various countries ${ }^{[1]}$.

The postpartum period is a time when the mothers experience a change in their role. Postpartum mothers experience natural psychological changes due to physical and hormonal changes. However, these changes can be disruptive if not accompanied by support and care, especially if there are other psychological burdens ${ }^{[2]}$.

The anxiety experienced by postpartum mothers are the fear of being infected with COVID-19, the anxiety of not being able to breastfeed, and the anxiety of bleeding. Their source of anxiety could be from the absence of friends or family who would visit and care for their baby ${ }^{[3]}$. The impact of this anxiety is that the psychological burden of postpartum mothers could become complex and if not handled properly, it will affect the physical and psychological health of the mother and baby. During the postpartum period, women are at risk for mood disorders, one of which is postpartum blues ${ }^{[4]}$.

Based on the results of psychological research (anxiety and stress) in postpartum and breastfeeding mothers during the COVID-19 pandemic in the city of Bekasi in 2020 , the results showed that $64.56 \%$ mothers gave a normal response; $17.72 \%$ mothers had mild anxiety; $13.92 \%$ mother had moderate anxiety; $2.53 \%$ mothers had severe anxiety and $1.27 \%$ mothers had a very severe anxiety response. While $75.95 \%$ had a normal stress response; $13.92 \%$ had a mild stress; $7.59 \%$ had moderate stress and $2.53 \%$ had severe stress [5].
Relaxation techniques are methods, procedures, processes, or activities to help someone achieve a more relaxed, calm state, reduce anxiety and stress ${ }^{[6]}$. Relaxation can be achieved, one of which is by hypno-breastfeeding applied to breastfeeding mothers so that anxiety could be decreases and mothers can be more relax and calm so that the milk production process goes well ${ }^{[7]}$.

Considering the impact of anxiety in postpartum and breastfeeding mothers on physical and psychological health, the researchers were interested in determining the effect of hypno-breastfeeding on anxiety of postpartum and breastfeeding mothers during COVID-19 pandemic at South Denpasar Health Center III.

\section{METHODS}

This research is quasi-experimental research with one pretest-posttest group only, without control group. In the initial provision of hypno-breastfeeding, the samples were accompanied by a psychologist and given music. The hypnobreastfeeding method is a relaxation technique starting with the stages of muscle relaxation, breath relaxation, and mind relaxation by including positive suggestions and affirmations. Furthermore, hypnobreastfeeding is done at home by providing a video guide that has been made by researchers and psychologists. Hypnobreastfeeding is done 1 (one) time a day for 6 days.

The independent variable of this research is hypno-breastfeeding, while the dependent variable is anxiety. The sample of this study was breastfeeding mothers who met the inclusion criteria, which are breastfeeding mothers who had babies 0-6 months, mothers who breastfed, and mothers who experienced anxiety. The exclusion criteria were mothers who were confirmed positive for COVID-19, mothers who were not willing to be respondents, and mothers who were unable to communicate well/uncooperatively. The 
sampling technique used was purposive sampling. The study was conducted at South Denpasar Health Center III with a total sample of 32 postpartum and breastfeeding mothers.

The measuring instrument in this study was the Zung Self-rating Anxiety Scale (ZSAS) questionnaire which was given before the intervention and after the 7 th day of intervention. The value of $r$ count $>\mathrm{r}$ table (valid) and Cronbach's Alpha value (0.969) > 0.60 (reliable). Data analysis was computerized using the SPSS program with statistical test of $t$ test.

\section{RESULTS}

\section{Univariate Analysis}

Table 1. Characteristics of Respondents

\begin{tabular}{lcc}
\hline $\begin{array}{l}\text { Characteristics } \\
\text { of Respondents }\end{array}$ & (f) & $\%$ \\
\hline $\begin{array}{l}\text { Age } \\
\text { <20 years old }\end{array}$ & 2 & 6 \\
20-35 years old & 29 & 91 \\
>35 years old & 1 & 3 \\
Education & & \\
Low & - & \\
Intermediate & 19 & 46.7 \\
High & 13 & 53.3 \\
Employment & & \\
Employed & 17 & 53.1 \\
Unemployed & 15 & 46.9 \\
\hline
\end{tabular}

Table 1 shows most of the respondents are aged 20-35 years old (91\%), 19 respondents (46.7\%) had secondary education, and 17 respondents $(53.1 \%)$ were employed.

Table 2. Anxiety Levels Before Giving Hypno-breastfeeding

\begin{tabular}{lcc}
\hline \multicolumn{1}{c}{$\begin{array}{c}\text { Anxiety } \\
\text { Levels }\end{array}$} & (f) & \% \\
\hline Normal & 0 & 0 \\
Mild & 7 & 22 \\
Moderate & 21 & 65 \\
Severe & 4 & 13 \\
\hline
\end{tabular}

Table 2 shows that most of the 21 respondents $(65 \%)$ were in the moderate category before being given hypnobreastfeeding.
Table 3. Anxiety levels after being given hypno-breastfeeding

\begin{tabular}{lcc}
\hline \multicolumn{1}{c}{ Anxiety } & (f) & \% \\
\hline Normal & 5 & 15 \\
Mild & 15 & 47 \\
Moderate & 12 & 38 \\
Severe & - & \\
\hline
\end{tabular}

Table 3 shows that after being given hypnobreastfeeding, 15 respondents $(47 \%)$ had mild anxiety.

\section{Bivariate Analysis}

Based on the normality test (Kolmogorov) on the distribution of anxiety, it was found that the significant value for pretest anxiety was 0.054 and posttest anxiety was 0.115 which was higher than 0.05 . The data was normally distributed, so to test the difference in anxiety values, it was continued with the $T$ test.

Table 4. Bivariate Variables

$\begin{array}{lll}\text { Anxiety } & t & \text { P value }\end{array}$

\begin{tabular}{lll}
\hline Pre-posttest & $6.851 \quad .000$
\end{tabular}

Table 4 shows the t-count value of 6.851 with a p-value of (0.000). There is a significant effect of postpartum and breastfeeding mothers' anxiety before and after being given the hypno-breastfeeding intervention.

\section{DISCUSSION}

Mothers during pregnancy, childbirth, postpartum and breastfeeding experience psychological changes naturally due to physical and hormonal changes. However, these changes can be disruptive if not accompanied with support and care, especially if there are other psychological burdens. The spread and transmission of the SARS-CoV-2 virus was so fast that it was stated a COVID-19 pandemic. The pandemic requires the government to establish several rules to suppress the 
spread of the virus and this has an impact on people's psychology, including postpartum and breastfeeding mothers ${ }^{[8]}$.

Relaxation interventions induce a state of relaxation which is a physiological response in the body as opposed to the stress response. The relaxation response, elicited through various relaxation techniques, reduces the activity of the sympathetic nervous system and, thereby, offsets the stress response ${ }^{[9]}$. The relaxation response simultaneously activates the parasympathetic nervous system, resulting in a decrease in metabolic muscle tension, an increase in the calming effect, and a pleasant mood so that postpartum mothers could have a calm and comfortable mood, and so it will affect the milk production.

Relaxation in breastfeeding mothers, often referred to as hypno-breastfeeding relaxation, is a relaxation technique by making direct contact with the subconscious. When you are able to achieve a deep and stable state of relaxation, you will be able to set a new concept that will automatically affect your daily life and actions without realizing it, in this case setting suggestions of self-confidence to be a mother, being able to take care for her baby properly, and can provide the best nutrition for babies. The basis of hypnobreastfeeding is the use of the ability to directly access the subconscious, because the subconscious is the part of the brain that runs life, regulates actions that is done every day ${ }^{[10]}$.

The success of relaxation is that the mother is able to do self-hypnosis. The therapist may not always be able to accompany during the relaxation process, so mothers are taught to do hypnosis induction, deepening relaxation techniques, and set the hypnotic suggestions [11]. Mothers are taught how to use selfhypnosis to prepare themselves for situations that cause anxiety. During selfhypnosis, mothers are trained to imagine coping with impending stress and apply hypnotic suggestions to reduce anxiety and build self-confidence. So that when self- hypnosis is carried out continuously, all the anxiety experienced by postpartum mothers will be reduced. Self-hypnosis is a mean to overcome stress and anxiety experienced by mothers

This is in line with the research conducted by Kusmiyati that there is an effect of hypno-breastfeeding on anxiety and timing of breastfeeding in primiparous postpartum mothers in Yogyakarta. Hypnobreastfeeding relaxation can be done since the third trimester during pregnancy. It can be used to communicate with the baby and prepare for the delivery process and can reduce pain during labor ${ }^{[12]}$.

The same study was also conducted by Toosi with the result that there was a significant difference in reduced maternal anxiety between the group that was given the relaxation intervention and the group that was not given the intervention, with a $p$ value of $0.017^{[13]}$.

The results of Lenny Irmawati's research that post-partum mothers experience anxiety marked by mothers always being nervous, feeling afraid, feeling anxious, feeling uneasy and always having a bad feeling about COVID-19 on herself and her baby. Postpartum mothers have to prepare themselves to breastfeed their babies, but some mothers experience anxiety so that it affects the production of breast milk. Breastfeeding mothers must think positively and relax so as not to experience anxiety and the mother's psychological condition becomes good; a good psychological condition can trigger the work of hormones that produce breast milk $^{[5]}$.

Based on the results of research and supporting theories, researchers assume that the anxiety that occurs in postpartum mothers is because they think too much about negative things during the COVID-19 pandemic. Postpartum mothers should think positively, try to love their baby, and relax while breastfeeding. When mothers think positively and remain calm, it will trigger milk production so that breast milk can come out smoothly. On the contrary, 
mothers whose psychological conditions are disturbed, such as feeling anxious, will cause decreasing milk production.

\begin{tabular}{c} 
CONCLUSION \\
\hline There is a significant effect of
\end{tabular}
anxiety in breastfeeding mothers before and after being given hypno-breastfeeding. Based on the results of this study, suggestions can be given to further researchers so that other variables should be determined to support the exclusive breastfeeding program.

Health services are advised to socialize hypno-breastfeeding techniques or include them in the class program for pregnant women as a preparation for mothers to enter their new roles, to avoid anxiety and postpartum blues, which will have an impact on the breast milk production.

For the community and breastfeeding mothers, it is recommended to apply hypno-breastfeeding as a solution to be successful in exclusive breastfeeding.

\section{REFERENCES}

1. Yuliana Y. Corona Virus Diseases

(Covid-19):Sebuah Tinjauan

Literatur. Wellness Heal Mag

2020;187-192.

2. Marmi. Asuhan Kebidanan Pada Masa Nifas "Puerpureum Care." 2014.

3. Bender, W.R., Srinivas, S., Coutifaris, P., Acker, A., Hirsberg A. The Psychological Experience of Obstetric Patients and Health Care Workers After Implementation of Universal SARS-CoV-2 Testing. Am J Perinatol 2020;37(12):1271-9.

4. Ahmad M, Maryam SB, Bilal U, Hafiz SA, Nayab I UM. Prevalence of depression in an urban setting. Biomed Res 2015;26(4):765-70.

5. Lenny Irmawaty Sirait, Yafi Sabila Rosyad, Ernauli Meliyana, Dyah Maria Ulfah CP. Stress and Anxiety in the Maternal During the COVID-
19 Pandemic. Int J Contemp Med 2021;9(2):7-13.

6. Hawari D. Menejemen Stres, Cemas dan Depresi. Jakarta: FKUI; 2016. MM E-AK and A. Effect of Relaxation Exercises on Postpartum Depression. Int J PharmTech Res 2016;9(3):9-17.

8. Kadjdy, A., Feduniw, S., Ajdacka, U., Modzelewski, J. D. Risk factors for anxiety and depression among pregnant women during the COVID19 pandemic. Aweb-based crosssectional Surv Med 2020;99(30):1-7.

9. Kusumawati F. Buku Ajar Keperawatan Jiwa. 2017.

10. Araujo WS, Walckiria GR, Eliana Z $\mathrm{MH}$. Effects of relaxation on depression levels in women with high-risk pregnancies. Rev Lat - Am Enferm 2016;24(3):e2806.

11. Stuart W. Buku Saku Keperawatan Jiwa. 2017.

12. Kusmiyati Y WH. Pengaruh Hypnobreastfeeding terhadap kecemasan dan waktu pengeluaran ASI pada ibu postpartum primipara di Yogyakarta. J Teknol Kesehat 2014;10(2).

13. Toosi, M., Akbarzadeh, M., \& Ghaemi Z. The Effect of Relaxation on Mother's Anxiety and MaternalFetal Attachment in Primiparous IVF Mothers. J Natl Med Assoc 2017;109(3):164-171. 